DOI: $10.2478 /$ pof-2018-0038

VOLUME 10, ISSUE 3, 2018

ISSN: $2036-5438$

\title{
Bi-Ethnic Federalism and the Question of Sovereignty: \\ Understanding the Competitive Security Postures in \\ Cyprus
}

by

Pavlos I. Koktsidis*

Perspectives on Federalism, Vol. 10, issue 3, 2018 


\begin{abstract}
When ethnic groups negotiate self-government arrangements, 'ethnic sovereignty' lies boldly at the heart of their security considerations. The constitutional nature of selfdetermination and the extent of territorial control can determine the degree of ethnoterritorial sovereignty attributed to groups. However, in competitive contexts influenced by fear and mistrust, groups interpret these pillar elements in ways that increase their own sense of security. The present study argues that legal and political positions on sovereignty in Cyprus are largely built around the competitive security assumptions held by the Greek and Turkish Cypriot leaderships, and explains how the divergent viewpoints and understandings of sovereignty reflect the underlying security fears and suspicion of parties. The analysis finds that the two ethnic leaderships in Cyprus have sought to accumulate a distinct 'sovereignty capital' in an effort to safeguard their own and overpower each other's perceived security intentions in the event of federal collapse, making thus the attainment of settlement in Cyprus particularly elusive.
\end{abstract}

\title{
Key-words
}

federalism, territory, sovereignty, security, conflict, Cyprus 


\section{Introduction}

In most ethnic conflicts, the nature and expressions of sovereignty represent part of the conflicting interests and objectives held by groups. The inextricable link that associates sovereignty with power, territory and international status is generally acknowledged since rules defining the nature and extent of sovereignty help in facilitating or even shaping the political, economic, security or ideological objectives pursued by actors (Krasner 1999). Yet, as Richmond puts it, 'the notion of sovereignty is especially flawed in the case of ethnic groups within states in their attempts to gain (and preserve) status and security in the international system' (Richmond 2002: 381).

In the case of Cyprus, subsequent failures to achieve a 'fair, viable and functional' solution signify the increasingly diverging 'visions and expectations' held by the Greek and Turkish Cypriot communities (Koktsidis 2017; Sözen \& Özersay 2007). However, interethnic competition in Cyprus is not merely expressed through the obvious security concerns related to effective governance, third-party guarantees and intervention rights, which noticeably create a problematic situation, but it is also manifested through notions of 'constitutional security', linked primarily to the groups' ethnic, political, and territorial standing in a conceivable ethno-federal state.

As realised by Denisson Rusinow in 1981, the question of sovereignty and legitimacy in Cyprus is intrinsically important for its underlying political and security dimensions' (Rusinow 1981: 15). Rusinow recognized that 'the nature of sovereignty and legitimacy in a proposed Federal Republic of Cyprus is one among those difficult issues which at first glance seems highly abstract but oddly important' (Ibid). This is a sign that more is involved here than a sterile and unnecessary debate over the concepts of sovereignty and federal statehood (Ibid). Again, according to Rusinow's early remarks, 'it is in the superficially symbolic question of sovereignty and legitimacy that conflict values, emotive interests, and deep-seated mutual distrust and fear are most "real" and hard to reconcile" (Ibid: 13). Two decades later, Oliver Richmond recognized that disputing parties in Cyprus have engaged in inter-communal talks with a view to trump each other's sovereignty claims (Richmond 1999). 
The present study suggests that alongside to the prominent military aspects of security, there is another, perhaps equally important facet of political security related to the legitimate source of self-determination and sovereignty. The analysis attempts to review the divergent notions of self-determination and sovereignty as underlying sources of tension through the lens of an adapted security framework according to which 'one party's security, increases the other party's insecurity' (Snyder \& Jervis 1999: 15; Posen 1993). The present study scrutinizes how competitive security concerns give birth to different 'readings' of the rules and context of sovereignty and self-determination in Cyprus. The analysis argues that sovereignty-related contrasts are linked to and in service of both sides' distinct security perceptions, impeding thus the attainability of a settlement. The study begins with a theoretical description of the way in which contested notions of sovereignty embolden insecurity and strengthen competition and sheds some light on the unjustly sidelined influence of 'security perceptions' reflected on the legalistic and political attitudes adopted by negotiating parties in Cyprus. Essentially, the analysis attempts to present the competitive security environment as reflected on the distinct interpretations of the origin and nature of state sovereignty shaped over years of conflict, fear, and mistrust. The analysis develops with a view to understanding the antagonistic security perceptions that shape and affect the legal and political standing of groups during the conflict resolution process.

\section{A competitive security framework}

Similar to interstate relations, ethnic groups appear to be influenced by deep-cutting security considerations that become particularly intense when questions of 'fear and trust' and the perception that there is no 'credibility of commitment' predominate amongst politicians and their ethnic constituencies. Elements of fear, mistrust and systemic uncertainty can decisively influence the formulation of attitudes (Butt 2011: 13; Fearon 1995; Posen 1993).

As security dilemma theorists put it, the indistinguishability of one party's malign (offensive) and benign (defensive) intensions heightens the level of uncertainty (Posen 1993; Rose 2000; Roe 1999). What one party does, claims or demands for increasing or protecting its security status may be sufficient to making another party less secure and 
encourage a competitive reaction (Posen 1993). Parties may often feel that "what seems sufficient to one's defence, will seem, or will often be offensive to its neighbours... and because neighbours wish to remain autonomous and secure, they will react by trying to strengthen their own positions, even if they have no explicit evidence of expansionist (or aggressive) inclinations' (Ibid: 104-106).

Booth and Wheeler (2008) suggest that under conditions of uncertainty 'parties involved in conflict are faced with the difficult choice to decide if they should interpret the intentions or statements of another actor as threatening or aggressive, and thus adopt a stronger security posture in response, or if they should view them as defensive and thus exercise restraint to assuage their neighbour's security fears' (Booth \& Wheeler 2008: 30). Ethnic parties involved in competitive political frameworks are faced with a similarly difficult choice of interpreting intentions. Notions of self-help, fear and mistrust, as well as the indistinguishability of offensive over defensive intentions conveyed by groups will usually come into play (Saideman \& Zahar 2008; Rose 2000). For example, provisions related to self-government powers can drastically affect the attractiveness of a compromise, presuming that the security of one party is seen to be working at the expense of the other. Most often, rival ethnic parties enter negotiations with the whole load of bitterness, suspicion, and fear built at length during the conflict. In Cyprus, the incurring fear over each other's real intensions has cultivated an evolving trust deficit over vital security matters reflected during negotiations (Koktsidis 2017). More precisely, fear of deception, abuse, or misuse of provisions set by an agreement prompts parties to overpower each other in an attempt to buttress their security defences at the event of a federal break down. Hence, the fear of a specified constitutional status allowing or preventing the projection of a viable claim for 'distinct ethno-territorial sovereignty' constitutes the non-military epicentre of contention.

Group negotiators evaluate the security provisions of a proposed settlement and parallel assess the costs of disloyalty and defection. Ethnic group representatives calculate what the future will look like according to their own set of incentives, fears and constrains. Calculations also focus on gaining and maintaining access to political power, territorial control, and resources, or imposing the constitutional restrictions that would help bridle the opponent. Hence, parties assess the quality of compromise on the supposed security conditions it entails, and then compare these to their current security status. Fear, 
insecurity, and distrust will normally continue to cast their shadow over efforts to resolve conflict and cost-benefit calculations will continue to influence decisions to act (Putnam \& Wondolleck 2003). This fosters the adoption of competitive strategies during negotiations akin but not similar to an ethnic security dilemma (ibid). Parties interpret behaviour and objectives with mutual fear and suspicion, turning the negotiation process into a firm contest for ensuring that a settlement would not impinge against their defined security interests.

Cooperation to mute these competitions can be difficult because someone else's 'betrayal' may leave one in a weakened position since no side can credibly assure that it would not take undue advantage of its gains (Posen 1993; Butt 2011). According to Posen (1993), this is particularly true with respect to the future of the state and its territorial coherence. For example, both parties in Cyprus are well aware that every sector-related arrangement, which is to come about following a comprehensive agreement, will tie parties to a certain security framework. First, both parties have been pressing to create or alter those military-related security parameters (third party military forces, guarantees, and intervention rights) that will permit them to instil a sense of communal security. Secondly, judging from their stated positions, both parties are deliberately seeking to promote secure living conditions that will address their distinct 'security needs' in a post-agreement environment through mechanisms contained in a robust and secure constitutional framework. In every single attempt to resolve outstanding issues, security lies boldly at the centre of concern for both ethnic communities.

\section{Ethnic sovereignty: self-determination and territory}

Perceptual disharmony on the nature and extent of sovereign control in ethno-federal state-building processes increases fear and suspicion. Ethno-federal power-sharing arrangements between equally suspicious parties are often marked by political and legal contestations on sovereignty relevant to the distinct security interests held by parties (O'Leary \& McEvoy, 2003). Defining the nature and extent of the right to selfdetermination and setting the legal rules under which territorial entities can predictably function are of pivotal importance in the construction of ethno-federal states. 
When it comes to defining multitier sovereignty arrangements of federal states in international law, a common concern arises: do federal sub-state units possess a separate legal international personality? Moreover, how are they to be regarded as distinct subjects in international law following a federal collapse? A well-defined notion of sovereignty is a sine qua non for a credible and workable ethno-federal arrangement, one in which all rights and constrains of federated entities are stipulated clearly in the federal constitution. In principle, according to Crawford (2006), when states choose to federate, they lose their standing as entities of international law. Instead, the federal union as a single entity becomes the sovereign state for purposes of international law. Nevertheless, in legal international practice, federal components can possess a limited measure of distinct international personality, which although separate, it must be in accordance to the federal state's constitutional provisions. For example, federated territorial entities with the power to contract internationally binding legal obligations such as in the form of treaty making powers, may qualify as legal persons in international law.

However, even such constitutionally endowed treaty-making powers remain controversial in international law. On the one hand, some authors support that when federated entities enter into treaties, they are only acting on behalf of, or as agents of the federal state, since only the latter possesses international legal personality (Fitzmaurice 1958: 84; Brownlie 1998: 59-60). According to Wouters and De Smet (2001: 4), 'the defenders of this so-called 'organ theory' underpin their view mainly with two arguments: first, they refer to Articles 1 and 6 of the 1969 Vienna Convention on the Law of Treaties, which deal with the treaty-making power of states under international law' (Wouters \& De Smet 2001: 4). Secondly, 'they revert to the 'sovereignty principle' according to which only states as such can be subjects of international law, since they alone have full and indivisible sovereignty, and unlike international organizations, any attribution of treaty-making powers to federated entities would be an unacceptable impairment of sovereignty' (ibid: 4). ${ }^{\text {I }}$ Besides, a constituent state in federation is a territorial and constitutional entity forming part of a sovreign state (Shaw 2017: 178).

On the other hand, although states continue to be seen as primary subjects of international law, this status is nowadays no longer exclusively reserved to them (Steinberger 1967: 5). Wouters and De Smet argue that the idea that non-sovereign entities can also be endowed with international legal personality follows the International Court of 
Justice statement that 'the subjects of law in any legal system are not necessarily identical in their nature or in the extent of their rights, opening the door for the recognition of other actors, including federated entities of states as international legal persons' (Wouters \& De Smeet 2001: 5-6). In addition, empirical practice of attributing treaty-making competencies to federate or autonomous territorial entities supports this position (e.g. Catalonia, Basque Country, Scotland, Wales, Bavaria, and Flanders).

Be it as it may, the principal criterion for component states to be considered as subjects of international law rests on the provision of competencies in accordance with the federal constitution and their capacity to exercise them (Kelsen 2003: 170). In practice, federal entities can be considered as subjects of international law only after they have concluded at least one international treaty and thus they have become bearers of rights and responsibilities under international law. As accurately put by Stern, this means that 'by attributing treaty making powers to federated entities, federal constitutional or other legal documents only give them a potential status of subjects to international law' (Kovziridze 2008: 254).

In this way, the attitude of the international community essentializes the rights given by domestic constitutional law to the federated entities, but also determines willingness to acknowledge a federated entity as a legal subject of international law (ibid: 127-129). In any case, the recognition of the international legal personality of federated entities remains limited within the range of its competencies. Thus, it is confined within international law as a corollary to the relevant constitutionally defined prerogatives provided by the federal constitution to the entity and hence federated entities can only be partially and conditionally separate subjects of international law and always within their respective sectors of competence in relation to the federal state (Hernadez 2013: 509). However, it is feared that the status and capacity of federated or autonomous entities to regulate treaty-making powers and pursue independent foreign transactions provided by domestic law, may open the door for entities to acquire a degree of 'stand-alone' international legal personality. This testifies to an expression of statehood, such in which at the event of federal dissolution would lead to the assumption or acknowledgement of broader external sovereignty rights (Alen \& Peeters 1998: 122-124). Hence, this limited exercise of external sovereignty brings us back to the core of the security question: following the dissolution of an ethno-federal 
state, what are the possible constitutional and political grounds of an ethnic federated entity to claim independent statehood?

Again, this cannot be firmly answered since ethno-federal states and autonomous entities vary in constitutional form. Federated entities can have different capacities (effectivite) and different prospects of recognition. Sceptics on the suitability and viability of ethno-federal arrangements argue that the depth and breadth of ethno-territorial selfgovernment arrangements determine the capacity and prospects of recognition and the willingness to secede. In fact, research on the viability of ethnic-federations, which is the type of ethno-territorial self-government arrangement that interests us most, has produced contradictory results. Roeder's empirical evidence suggests that ethno-federalism approximates both a necessary and sufficient condition for a variety of pathologies, but mainly secession (Roeder 2009). According to Roeder, ethno-federal arrangements 'privilege some identities and interests and distribute coercive and defensive capabilities in a way that increases the likelihood of escalation of conflict into acute nation-state crises' (Ibid: 203-219). Cornell suggests that the perceived susceptibility of ethno-federations to secessions may be due to an intuitively plausible causal logic focused on how ethnofederalism increases both the capacity and willingness of ethnic groups to secede from the common state' (Cornell, 2002: 245-276). Secession would appear to result from an interactive combination of enhanced capacity and desire that is uniquely present in ethnofederations, and absent in other system types (Ibid: 252).

A real-world picture shows that full ethno-federations do indeed have a low success rate (33 percent) relative to other territorial self-government arrangements (Anderson 2014: 197-202). Beyond full ethno-federations, the success rate including more centralised federal arrangements, quasi-federations or other variant autonomy arrangements other than full ethno-federations increases significantly (79 percent) (ibid). The data suggests that some self-government systems have failed, but many more have not, whereas those that have failed are almost exclusively full ethno-federations in contrast to other autonomy arrangements or ethnic federacies (non-territorial).

In any case, the extent to which statehood claims may flourish depends largely on the constitutional, organizational and legitimacy capital ethnic groups have succeeded to garner in conjunction with international norms and subjective practices on state recognition. For example, European ethno-federalists such as Guy Héraud advocated in favour of federated 
entities having a specific "ethnic value" while possessing their own sovereign powers and capacities to arrange their living space independently, ideally with regard to their given socio-cultural and regional characteristics (Héraud 1963; Visone 2018: 30). Negotiations involving ethnic groups in search of ethno-federal solutions often degenerate into arguments over status in order to attain or confirm a degree of sovereignty and legitimacy that will allow some space for manoeuvre in the future (Richmond 1999: 396). The present analysis agrees that these levels of capacity and willingness depend upon two fundamental constitutional pillars that provide ethno-federated entities with the armoury to exert sovereignty and assert statehood. These are namely: a constitutionally recognized right to a distinct self-determination, as separate peoples, and the extent and type of territorial selfgovernment. These two elements combine to determine the nature and degree of 'ethnic sovereignty' (ibid). In fact, we would argue that the constitutional depth and extent of ethnic sovereignty reflected on the exercise of absolute and exclusive political authority over a designated territorial domain determines the efficacy of independent statehood.

Ethno-federal constitutions must primarily define the composition and selfdetermination rights of the national constituency (the people) and then specify the legal nature of the territorial-administrative status (national homeland) of the federated entities. First, ethnic self-rule ranging from autonomy to independent statehood stems from a recognized, although often limited, right to self-determination. Yet this remains an essentially contested political concept (Kurtulus 2005). In elementary international law, sovereignty means that a government possesses full control over affairs within a geographical area. Yet it is crucial to identify and agree on the constituency or political body that legitimizes sovereignty claims in the first place and define by what right does a government exercise authority, and who possesses rightful ultimate authority over territory in an ethnically layered federal state. The right of self-determination i.e. the politically expressed will of a political collective to self-govern itself constitutes the basis for asserting a degree of ethnic sovereignty. Although according to the UN Charter, 'people have the right to freely choose their sovereignty and political status with no interference', the principle does not state the delimitation between peoples nor what constitutes the 'people', other than its goal of decolonisation (Del Mar 2013: 97; Richmond 1999: 389).

In general, this vague demand for self-determination leading to sovereignty must be both defined and recognized as the rightful exercise of independent communal will by an 
internationally valid legal framework or at least through recognition by other legal entities on a bilateral basis. Hence, the prospect of ethnic federated entities becoming independent depends on the preceding constitutional provisions determining the right of selfdetermination and the political competence in exerting it.

The extent and type of territorial self-governance within federations is primarily a matter of assigned constitutional status to the federated entities coalescing with a distinct right to self-determination, and with the power to establish or give organized existence (enact) to the federal state. The status of constituent units in ethnic federations is either determined by the right to allow sovereign and non-retractable constitutional powers to the units, while retaining the original legitimate source of power or residue (top-down federalization) at the centre, or by attributing the original source of legitimate power and authority to order, establish and enact a new state of affairs to the ethno-territorial units or communities themselves (bottom-up federalization). In fact, the constitutional process by which a federation comes to life (bolding together vs coming together), could possibly assist asserting international recognition. The distinction lies on the legal understanding of the federal units, which either emphasizes the sovereign primacy of the community that decides to concede voluntarily some powers to the federal centre or highlights the predominance of the federal centre's sovereign power that provides component units, and their people, with constitutionally protected rights to exercise sovereign powers.

Nonetheless, the relationship between ethnic groups and territory is fraught by conflicting claims, between normative, historical and strategic interpretations of territorial possession and rights of autonomy implying a degree of ethnic sovereignty (Richmond 1999: 386). For ethnic groups in particular, territory is not just a geographical focal point. Territory is conceptualized more appropriately as a place, bearing significance in relation to the group's history, collective memories, and 'character' but also because territory can become a valuable tangible asset or commodity as it provides resources and a potential power base (Wolff 2010: 18). Asserting, enforcing and solidifying territorial claims makes concrete power relations and therefore territoriality i.e. control of space, becomes inextricably tied to questions of power, authority and security, since traditionally only through control over its own territory can an ethnic group achieve full political freedom and cultural expression (Murphy 1996). As pointed out by Murphy, the problem of territorial heterogeneity or rival ethno-territorial claims, and the purity and ownership of 
land, is usually resolved by a group's capacity to manage or enforce violently or nonviolently some degree of control over territory (ibid). For that reason, ethnic groups often strive to control territory and make it an indivisible condition for claiming sovereignty and recognition (Toft 2001). This fusion of territory with ethnic politics created by a merging of an ethnic group's identity and spatial control is usually described as 'ethno-territoriality' (Moore 2015: 4).

Although norms of international law do not root themselves in territorial claims, but rather whether the aggrieved group constitutes a distinct people, territory continues to play an important part in asserting sovereignty claims (Storey 2001: 14; Sack 1986: 26). Yet it is typically acknowledged that regardless the constitutional arrangement, 'there is no contradiction between the right of self-determination and a state's territorial integrity, with the latter taking precedence while the prevalence of legality over unilateral secession is generally accepted (Constantinides \& Christakis 2017). ${ }^{\text {II }}$ Although the sanctity of the state's overarching territorial and political sovereignty as a single and indivisible legal entity is formally confirmed, it is nevertheless challenged by the 'sovereignty capital' accumulated by parties in legal specifications regulating self-determination and territorial control in ethnofederal states. Uncertainty, and the politics rather than criteria of state recognition can create tension between the state's overarching sovereignty, the internal right to selfdetermination and territorial self-rule, prompting parties to compete over provisions that reinforce the one over the other. Insecurity and the loss of sovereign status stem from the belief that the constitutional basis which recognizes a distinct ethnic right to selfdetermination attributed to the will of separate peoples, facilitates a partial re-entry of ethno-territorial entities into the international system, and paves the way for recognition. To put it more succinctly, although secession is rarely viewed with sympathy (Gudeleviciute 2005; Buchanan 1997; Pavković \& Radan 2007), a constitutionally recognized right to internal ethnic sovereignty signifies a right to self-determination manifested through the expressed consent and 'will of a separately defined people' that make a state truly legitimate. ${ }^{\text {III }}$

Clearly, at least within the framework of ethnic federations, there is an inextricable link between the source of self-determination (constituency) and territorial self-rule as a reflection of it. For example, in the case of former Yugoslavia, nationalities were typically equipped with a constitutionally protected right to distinct self-determination corresponding with the 
national territories (Republics) that comprised the federation despite the geographical dispersal of ethnic groups, which created tensions between territoriality and selfdetermination. ${ }^{\text {IV }}$ It was widely accepted that based on constitutional provisions Yugoslav republics had the right to independent statehood by asserting their distinct national selfdetermination rights within their demarcated borders. A more glaring prevalence of selfdetermination over state sovereignty and territorial integrity appeared in the case of Kosovo. Germany recognized Kosovo's 2008 declaration of independence even though it has not constituted a federated unit within Yugoslavia by referring to the right of 'self determination by the people of Kosovo' to rule over a designated territorial compound (ICJ Hears further Kosovo arguments: Balkan Insight. 2 December 2009). By contrast, Russia has officially positioned herself against the case of Kosovo's declaration of independence claiming that 'agreement is the only means of legal partition or secession and therefore recognition of external sovereignty...while stressing the obligation to respect the territorial integrity of Serbia which precedes over the principle of self-determination' (Ibid). ${ }^{\mathrm{V}}$

Although we recognize the major constitutional and structural differences between Kosovo and the proposed federal settlement for Cyprus, it is still important, as Eike Berg has rightly observed, to consider that the Kosovo case has created 'a self-determination precedent for states-within-states for which we still do not exactly know its ensuing effects' (Berg 2009: 219). Despite the differences, the case of Kosovo has empowered the unresolved antithesis between the 'will of the people' as the basic element in determining the final sovereign status of an entity, against the principle of the territorial integrity of states. It has also demonstrated that the congruity between a recognized right to selfdetermination and territoriality builds a robust case for supporting sovereignty claims despite the protection of a state's territorial integrity in international law and despite prohibitions of secession by domestic law. Taking into account the determinative role of political decisions on the right of independent statehood, competing ethnic groups strive to promote constitutional arrangements that do or do not provide a sufficient legal basis for claiming independent statehood in the event of state collapse.

\section{Sovereignty: a reflection of security postures}


This part of the study examines the articulation of security concerns reflected on the legal and political positions held by the conflicting parties in Cyprus. A disharmony between the two communities in Cyprus revolves around the question of which entity generates the primal legal rights of statehood: will the new federal state of Cyprus be made up of two sovereign constituent units (and their people), or a structurally reformed state will grant the two Cypriot communities with constitutionally protected territorial selfgovernment powers? Turkish Cypriots suggest that the two ethno-territorial entities will be coming together voluntarily to concede powers to a newly founded federal structure whereas Greek Cypriots suggest that the legal state i.e. the RoC, will be structurally transformed into a federal state by incorporating and granting two constituent units with constitutionally guaranteed self-government powers (Sözen \& Özersay 2006: 127).

The active phase of the interethnic conflict in Cyprus emerged during the 50s, at a time when Cyprus still existed under British colonial rule and in a political context within which Greek and Turkish communities had developed their own nationalist and competitive understandings of their right to freedom and self-determination. Greek Cypriots (approx. $80 \%$ of the population) pressed the British administration to allow them self-determination through Enosis - that was union with Greece, - whereas Turkish Cypriots (approx. 18\% of the population) reacted to this prospect and called for Taksim (partition). In 1960, both communities were forced to compromise by accepting the creation of a partnership state. In 1963, however, the partnership state paralyzed. Turkish Cypriot officials withdrew from state institutions and a series of violent events forced the two communities to grow further apart. In 1974, following a coup orchestrated by the Greek military junta, Turkish military forces invaded the island and occupied its northern part. The invasion resulted in the forceful expulsion of thousands of Greek and Turkish Cypriots from their original settlements and brought about the end of the island's ethnically mixed configuration through establishing a clear-cut territorial division between the two communities.

The territory over which Turkish Cypriots have declared their own independent state (1983) has ever since remained internationally unrecognized. Nevertheless, its demarcated areas correspond, almost identically, with the territorial dominion of a prospective Turkish Cypriot constituent state as designated in subsequent peace plans. Discussions to resolve the interethnic dispute and terminate the island's division have since then evolved under 
the auspices of the UN with a view of creating a federal consociational state. Despite progress over the years, a final settlement has not been achieved.

Characterised by a severe lack of common national belonging (beyond ethnic denominations), Greek and Turkish Cypriot perceptions have been shaped by experiences of the past, current insecurities, and strategic considerations, which altogether continue to shape preferences and subjective interpretations. Essentially, Turkish Cypriots fear that they would be cast out of the common institutions as they were in 1963, and the Greek Cypriots fear that the Turkish Cypriot gameplan is to negotiate a deal that consolidates the territory gained in 1974 and then secede, this time with international recognition. During negotiations, the primary concern is to ensure that both communities will safeguard their prospective security and rights in a new federal consociation, so that 'no community would be able to dominate over the other or take the other one hostage' (Ergün \& Rochtus 2008: 114). Parties seek to obtain mutual reassurances that will advance or maintain their current security status. Thus, the two parties are faced with a security challenge related to the question of sovereignty.

Most Greek Cypriots understand that by sharing sovereignty with the Turkish Cypriot community, they will be asked to abolish their exclusive legal right to statehood as a means to reunifying the island. (Burgess 2007: 135). However, shocked by the violent expulsion of more than 160.000 Greek Cypriots from their original settlements, where in most areas they constituted the majority population, most Greek Cypriots have difficulties in accepting the conversion or elevation of the secessionist entity into a constituent federal state. Furthermore, affected by the Turkish Cypriot minority's withdrawal (known among Greek Cypriots as the 'Turkish mutiny') from the 1960 consociational state, and traumatised by the ensuing forceful territorial division, Greek Cypriots fear that a bottom-up process will equip ethnic constituencies with an original, distinct and self-emanating right to selfdetermination-cum-sovereignty. In the occurrence of federal collapse, Greek Cypriots are weary that official partition may be legally sanctioned and that both entities will have an equal chance to assert their independent statehood. According to the Greek Cypriot viewpoint, legitimacy to independent statehood must be held at the federal centre, and legitimacy must be denied for whichever of the two constituent entities withdraws or secedes from the federal consociational structures. Considering the ad libitum political aspects that determine the recognition of states, Greek Cypriots strive to preserve legal 
international recognition at the federal centre in order to avoid falling into a legal international limbo, alongside with their Turkish Cypriot counterparts.

Turkish Cypriots are faced with a somewhat different question. Equally embittered by the Greek Cypriot's majoritarian logic (known among Turkish Cypriots as 'the Greek usurpation of state') during the 60s, they seek to ensure that legitimacy and sovereignty emanate from the ethnic groups contained within the constituent states. Hence, they need to ensure that a new federal constitution equips constituent states with self-emanating sovereign rights, which are to be 'rightfully' reclaimed in the event of dissolution, paving the way for claiming independent statehood. For the Turkish Cypriot leadership, a bi-zonal and bi-communal arrangement in Cyprus derives from 'an equally shared dual source of legitimacy' according to which entities retain sovereign control within their boundaries and voluntarily concede parts of it to the federal centre. According to this line of argumentation, executive and legislative powers are not conferred to the units by the centre but by the two people that willingly agree to share sovereignty by conferring competencies to the federal centre. Thus, in case either side wishes to withdraw from the federal structure it may rely on its self-emanating right to sovereignty with a capacity to retrieve powers that were voluntarily bestowed to the federal centre.

For the Turkish Cypriots, the original right and source of power-delegation does not emanate from within the federal centre (a top-down federalization of the RoC) but stems from the afresh willingness of two separate people and their constituent units to grant legitimacy to a new political centre (bottom-up federalization). This deprives the federal centre of its self-emanating sovereign powers and conditions its existence on the shared legitimacy and commitment granted by the two co-sovereign units. At the event of federal collapse, where one or both constituent units decide to call off the legitimacy granted to the federal centre, the two politically equal constituent states and their respective people must enter into a trail to de jure sovereignty by reclaiming the legislative and executive powers that were previously conferred to the federal centre. It is partially for this reason that Turkish Cypriots vested their support for the UN Comprehensive Settlement Plan for Cyprus in 2004 upon their insistence to ensure prior to any agreement that residual sovereignty stays with the Turkish Cypriot constituent state should a new federal state breaks down as in the 1960s (ICG 2014: 6).

According to Burgess's accurate ascertainment, 'what is at stake here is more than 
divergent perceptions: it is a matter of context and point of departure' (Burgess 2007: 135). As noted, ethnic groups develop their own perceptions of what sovereignty entails and how this is connected to their security (Richmond 1999: 394). The crux of the constitutional-security problem relates to the conditions under which Greek Cypriots, following a federal collapse due to Turkish Cypriot withdrawal, will return to the safety of the internationally recognized RoC, without legally sanctioning partition. On the opposite, Turkish Cypriots do not want to return to pariah status and hope a better deal on their status would ensure future universal recognition (Tocci \& Kovziridze 2004; Schlicher 2008).

The formal Turkish and Turkish Cypriot view on the matter starts from the premise that before a new partnership becomes a viable project, Greek Cypriots, as a first step, should acknowledge constitutionally and in practice the sovereign equality of the Turkish Cypriot people and territorial unit (Ministry of Foreign Affairs of the Republic of Turkey). ${ }^{\mathrm{VI}}$ In letter addressed to the Washington Times newspaper on 30 September 2014, Özdil Nami, the Turkish Cypriot Minister of Foreign Affairs and later Chief Negotiator for the Turkish Cypriot side, stated that:

The Turkish Cypriot and Greek Cypriot peoples, in their respective capacities as two political equals, entered into a partnership in 1960. The legitimacy of the 1960 republic lay in the joint presence and effective participation of both peoples in all organs of the state. (In 2004) the separate simultaneous referenda confirmed the fact that there exist two equal peoples on the island, neither of which represents the other...(hence) any solution in Cyprus requires the consent of both sides and both peoples (Özdil Nami, 'Turkish Republic of Northern Cyprus, Minister of Foreign Affairs', The Washington Times, 30 September, 2014) $)^{\mathrm{VII}}$

The Turkish viewpoint on state building is lucidly explained by adviser to the Turkish Cypriot side at the inter-communal talks back in 1999, as follows:

...taking into consideration the basic reality of the island by accepting the existence of equally sovereign peoples with different ethnic and religious identities entails a political structure that will ensure a new relationship between the two entities based on mutual respect and political equality on a specified range of functions between the two constituent peoples. It should be noted that both sides would bring their separate sovereign rights to self-determination and statehood on their respective territories to the process of settlement. As sovereign peoples, they have the inherent right to determine their destiny separately and to arrive 
together at an agreement for the future of Cyprus as a whole. As such, their relationship is not one of majority and minority (Soysal 1999: 6).

For the Greek Cypriots, however, 'reference to two constituent states does not form the starting point of the process, but the conclusion of the process' (Ministry of Foreign Affairs of the Republic of Cyprus). ${ }^{\text {VIII }}$ Their point of departure starts with the federalization of the legal state, and as such, the organization of the federal system cannot be based on the pre-existence of two distinct states because such do not exist (Burgess 2007: 136). The Greek Cypriot chief negotiator in the Cyprus peace talks, Andreas Mavrogiannis, explained the leap towards a federal state as an

'Evolution and continuation' of the existing legal state, i.e. the RoC, albeit under a largely modified constitutional form. The new structure will be introduced in order to reintegrate the lost territories into a reunified bi-zonal federal republic formed by two politically equal ethnic groups, a term mainly understood as a constitutionally protected right to self-govern and co-govern, and not as a separate provision for self-determination and independent statehood (Mavrogiannis 2016).

Therefore, the new state of affairs will be a continuation of the previous legally existing state of affairs, which is the RoC (Anastasiades 2016; Morelli 2017: 22). ${ }^{\text {IX }}$ By contrast, the Turkish Cypriot position holds that the new consensual partnership will involve an entirely new state structure, which will be created from scratch by two equal and sovereign constituent peoples and their territorial entities, replacing the RoC in all its respects (successor state thesis) (Berg 2007: 213). ${ }^{\mathrm{X}}$ Turkish and Turkish Cypriot diplomats have repeatedly emphasized that the new federal state will be product of mutual consent, granted by the two politically equal co-founding people, thus implying the recognition of sovereignty by the exercise of constitutionally guaranteed self-government and territorial control. Successive Turkish Cypriot leaders (Mehmet Ali Talat, Derviş Eroğlu and Mustafa Akinci) have consistently referred to a new partnership state founded by the constituent peoples and their respective territorial entities and rejected any idea of regarding the new federal structure as a continuation or transformation of the RoC (Morelli 2017: 22). ${ }^{\mathrm{XI}}$ In a formal announcement, Turkish Cypriot leader Mustafa Akinci has made it clear that he does not accept the idea of transforming or evolving the RoC into a federal state and stressed that the new federal structure will be made up by the two constituent states that 
will replace the 'defunct' RoC in all participating institutions. ${ }^{\mathrm{XI}}$ The new entity must not simply be a reformed RoC, but a new partnership. Besides, this is a firm and long-standing position expressed formally by the former adviser to the Turkish Cypriot side, Mümtaz Soysal:

A federation can only be based on the creation of a mutually agreed level of shared authority that results from the transfer of some parts of the sovereignty already possessed by the component political entities...and to bear no trace of supremacy of one entity over the other(s)... it is absolutely necessary that the partial transfer of power be made by entities that are equally sovereign, equally capable of transmitting part of their sovereignty to the federal authority (Soysal 1999: 5).

As rightly pointed out, 'obviously the issues involved go well beyond semantics' (Sözen \& Özersay 2006: 127). Security precautions and the fear of failure motivate the positions of both communities. There is little doubt that Cypriots in both communities profoundly suspect and therefore fear that the other side, through its attitude to the definition of sovereignty is betraying an undiminished but now secret adherence to an ultimate goal that has been now publicly renounced for temporary tactical reasons. These suspected goals are still partition for the Turkish Cypriots and for the Greek Cypriots, a 'Greek island' with a Turkish minority (Rusinow 1981: 15). These long-standing mutual bias, real or perceived, is driven by security considerations concerning sovereignty and state survival in a context of conflicting interests, uncertainty, suspicion, and fear emanating from their mutually distrustful attitudes. In their efforts to buttress their future prospects, both parties' claims are, perhaps even inadvertently, targeted against each party's core insecurities and are therefore viewed mainly as aggressive rather than defensive. Security concerns reflect the crude conflict over core state-building aspects, such as self-determination and territorial self-governance, which if not explicitly addressed, could serve as playground for dodgy political practices.

\section{Bridging the gap}

In a previous effort to bridge the two positions and appease the security fears of secession and/or domination, the former UN General Secretary's special envoy and 
mediator for Cyprus, Alvaro De Soto, 'crafted a 'constructively ambiguous' compromise to address competing views of where sovereignty for the new post-solution state would emanate, coined as "virgin birth" (Ker Lindsay 2011: 82). The so-called 'virgin birth' model, although it presupposed the inauguration of an entirely new federal state, it would nevertheless represent a continuation of two pre-existing states, which may be interpreted as a partnership between two presumptively existing states i.e. the de jure rump state of Cyprus, and the de facto breakaway Turkish Cypriot entity (ibid). Although this implied that the rump state is not 'defunct', it nonetheless accepted that the Turkish Cypriot breakaway state is separate and equal in the creation of the new federal state, providing communities with an implied right to leave the partnership and claim independent statehood (Ibid). The Annan Plan, however, was rejected by the vast majority of Greek Cypriots.

In a renewed effort to resolve the Cyprus Question, on 11 February 2014 President Nicos Anastasiades and Turkish Cypriot leader Derviş Eroğlu publicly presented a Joint Declaration. In some measure, the 2014 Declaration reaffirmed the same rough framework of those shared principles contained in the Annan Plan regarded by the two communities as a common acquis. ${ }^{\mathrm{XIII}}$ The Declaration stated that 'a federal settlement in Cyprus emanates equally from Greek Cypriots and Turkish Cypriots' (Art. 3), and that a 'federal constitution shall prescribe that the united Cyprus federation shall be composed of "two constituent states of equal status", and then referred to the "residual powers exercised by the constituent states" (Art. 3).

This rough description encapsulates the following fundamental state-building principles: i) two politically equal (ethnic) communities desire to form an independent federal state without reference to two pre-existing founding-states, ii) the federation shall be composed by two self-governing ethno-territorial constituent states that will also share power at the centre, iii) part of their sovereignty, mainly external, will be transferred by the ethnic communities to the central government while part of it (residue) shall remain at the constituent state level, iv) the federal government shall represent the single legal international personality of the state for international membership and representation, $v$ ) and finally, union in whole or in part with any other country or any form of partition or secession or any other unilateral change to the state of affairs will be prohibited.

At first glance, the Declaration recognizes that two constituent states represent the two politically equal communities agreeing to a federation. Yet the Declaration refers to the 
existence of 'two equal communities' with no explicit mention whether these communities make one, two or separate people, and without specifying a distinct right to ethnic selfdetermination-cum-sovereignty (internal) outside the proposed federal framework. Moreover, it does not explain whether these distinct communities form a common national constituency with an indivisible self-determination or if they will concurrently exercise their separate rights to self-determination only as a prerequisite to forming a federation. XIV However, it appears that the ethno-federal units shall contain guaranteed majorities of the two distinct and politically equally communities comprising two distinct constituencies on the constituent state level and one perceivably common constituency on the federal. Naturally, one may suggest that prohibitions on partition or union with other states limit self-determination within the federal framework. Hence, we may suppose that the right to exercise concurrent self-determinations is meant only as part of a federal solution and it is strictly framed, delimitated and predefined to associate only and exclusively with the creation of a federal state. Yet according to the Turkish Cypriot side, the Declaration points towards the existence of two separate rights of self-determination, which according to the international law is granted to the 'communities' as a legitimate political body.

Furthermore, the term 'residual powers' could either imply bottom-up federalization, signifying a primary and self-accrued sovereign authority to the constituent units or topdown federalization, as the residue of powers granted to constituent states by the federal centre. At the same time, the Declaration restates the single international legal personality and the single sovereignty of the state 'defined as the sovereignty which is enjoyed by all member States of the United Nations under the UN Charter and which emanates equally from Greek Cypriots and Turkish Cypriots'. Since sovereignty emanates equally from the two communities - represented by their territorial entities - with a capacity to concede and retain authorities, then, this perceivably functions to the benefit of the Turkish Cypriots in a way that appeases fears of subordination and minoritization. Finally, according to the Declaration there will be a 'single united Cyprus citizenship', regulated by federal law. However, all citizens of the united Cyprus shall also be citizens of either the Greek-Cypriot constituent state or the Turkish-Cypriot constituent state. The Declaration clarifies that this status shall be internal and shall complement, and not substitute in any way, the united Cyprus citizenship (Art. 3). 
On the surface, the spirit of the Joint Declaration coincides with Monroe Leigh's opinion that sovereignty would devolve fully and legitimately to any new federal Cypriot government as a product of a concurrent exercise of self-determination by the two communities' (Leigh 1990). However, Leigh argued that powers would be devolved to the new Cypriot government (from the federated states) as a means of accomplishing a concurrent (i.e. an agreed and simultaneous) exercise of sovereignty (ibid). Yet Leigh presumed the preexistence of two self-acting states and not just their peoples exercising a concurrent right of self-determination, something that is not contained in the Declaration. The Declaration recognizes the existence of two politically equal communities that shall be contained in two constituent states of equal status following an agreement but does not refer to the preexistence of separate states coming together to form a federation. Therefore, the Declaration is consistent with Security Council Resolution 541 (1983) because it signifies unwillingness to recognize the exercise of a distinct right to self-determination outside the constitutionally agreed federal framework and eliminates the possibility of equalizing the two territorial entities on the island outside an agreed framework. ${ }^{\mathrm{XV}}$

Serving as a rough guide to a future constitution, the Declaration designated the horizontal separation of powers, and highlighted the exclusiveness between federal and constituent state competencies. Both sides recognize that the 'single international identity', 'single sovereignty', and 'single citizenship' principles are sine qua non principles for a federation. Tufan Erhürman pinpoints that 'it is a well-known fact that in a federation, a constituent state does not have a different international identity from that of the federation in terms of international law' (Erhürman 2010: 36-37).

Nonetheless, Greek Cypriots would prefer the federal government to hold most utmost powers (strong federation) in order to cement the singleness of the federal state's sovereignty and deter Turkish Cypriot withdrawal. Turkish Cypriots would like to develop a model in which the constituent states have increased sovereign powers to prevent federal control and supremacy (Ibid: 38). Neither of the two sides trusts the motivation of preferring the one to the other. Greek Cypriots fear an intended Turkish Cypriot withdrawal and the development of a secessionist movement, whereas Turkish Cypriots fear an intended Greek Cypriot manipulation and domination through the federal structures (ibid: 36-37). 
In sum, the Joint Declaration equips constituent states with constitutionally protected internal (and probably limited external) sovereign powers, which if rightly understood, emanate from the two communities and are neither devolved from nor retrievable by a federal centre. Internal sovereignty, alongside with an explicit recognition of two communities (as separate and single constituencies) recognizes a distinct and joint right to self-determination but it does not provide ethnic communities with the legal means to controvert or replace the overall political sovereignty and territorial integrity of the single federal state. Therefore, constituent state competencies may legally function as part of an overall consociational agreement and constituent polities may therefore act as partial legal subjects in international law as they will be allowed to exercise their designated powers only within the federal framework.

Given the lack of trust and expected commitment, the discussed ethno-federal framework presupposes the making of a difficult trade-off. The security of the Turkish Cypriots depends upon the type and degree of sovereign powers endowed to them by an agreement conditional to the acceptance of an indivisible sovereign state. Similarly, the security of the Greek Cypriots relates to the indivisible sovereignty of the federal state, which is conditional to acceping sovereign powers transferred to the constituent units. As regards to the Turkish Cypriots, the transfer of substantial competencies to the federal units is crucial for enhancing their own sense of security, while for the Greek Cypriots, a more explicit reference to the indivisibility of the federal state's single legal sovereignty and overarching territorial integrity may be useful for unblocking their hesitations. Although parties have seemingly agreed on the future constitutional shape of the federal state, they remain hesitant in accepting institutional provisions that would help settle the question of distributing sovereign powers. Compromise is difficult because the two parties define the centre of constitutional gravity differently (centripetal vs centrifugal). As a result, they opt for institutional provisions in line with their clashing understandings of security. 


\section{Conclusion}

Defining and agreeing on the constitutional nature of sovereignty, as reflected upon the right to self-determination and territorial self-governance points to a major security concern because it may determine the position of the two communities and their respective territorial entities in the international system in case a federal arrangement breaks down. Motivated by fear and mistrust, and contemplating the political and security ramifications of state building processes and the possibility of federal collapse, Greek and Turkish Cypriots have been arguing about what would become the 'founding narrative' of a conceivable ethno-federal state in Cyprus. Naturally, the derivation and nature of an ethnic federation is hard to evade the question of sovereignty (Rusinow 1981). Turkish Cypriots have argued for the existence of two separate and equal communities currently residing in two territorial entities that will come together without sacrificing their distinct selfdetermination and territoriality while retaining much of their political sovereignty at the constituent state-level. Greek Cypriots argue that the de jure state of Cyprus (RoC) will be structurally devolved into a bizonal and bicomunal federation by granting constitutionally protected rights (internal sovereignty) to the two separate and equal communities by exercising their concurrent self-determinations within an agreed framework and with the emanating source of sovereignty retained at the federal centre. In fact, the new federal state will be neither a mere continuation of the Republic of Cyprus nor the creation of a new state by two pre-existing states. It is better conceivable that the federal structure will accommodate ex-nibilo the two ethnic communities in a new but indivisible sovereign state. The 2014 Joint Declaration provides a framework addressing some concerns, without fully or explicitly satisfying or annulling the positions held by the two communities.

In a perceivably competitive security context, however, the relative degrees of sovereignty and legitimacy will depend on whether trust and commitment will make it feasible for a trade-off to happen, setting thus the constitutional standards and security prospects for the two communities. The deliberate misinterpretation of state-building provisions and the deep-seated fear and mistrust reduce willingness to compromise when risks and corresponding costs of muddling on with a dubious solution are deemed higher than those of maintaining the status quo. How sovereignty is shared and practiced is much of a concern in Cyprus where parties seem to fear that a federal solution could simply keep 
the competing views and inbuilt suspicion of one another under wraps, forcing an instinctive preference for the evil one knows against the uncertainty inherent in the kind of compromise that could be presently achieved.

\footnotetext{
* Adj. Lecturer, Department of Social and Political Sciences, University of Cyprus. Email: pavlosk@ucy.ac.cy. I A sovereign state is, in international law, a nonphysical juridical entity that is represented by one centralized government that has sovereignty_over a geographic area.

II UN General Assembly declaration on the Rights of Persons Belonging to National, or ethnic, religious and Linguistic Minorities (art. 1,2 and 8) states "that States shall adopt appropriate legislative and other measures...to protect the existence and the national, ethnic, cultural, religious and linguistic identity of minorities within their respective territories, but (continues in art. 8) nothing may be construed as permitting any activity contrary to the purposes and principles of the UN, including sovereignty, equality, territorial integrity and political independence of states". See: Thomas D. Musgrave (2000). Self-Determination and National Minorities. Oxford University Press. p. 239.

III Notably, although in international law there is no rule that prohibits the declaration of independence, or secession integral parts of sovereign states, under international law, do not have a right to unilateral secession while the principle of protection of territorial integrity is a cornerstone of international legal order.

IV With the exception of Kosovo and Vojvodina which existed under an Autonomy Status within the Yugoslav Federal Republic of Serbia

v Counter-arguments suggest that Yugoslavia, to which UNSC 1244 referred to, had already been dissolved and succeeded by Serbia \& Montenegro.

VI Ministry of Foreign Affairs of the Republic of Turkey, "Where do the Parties Stand in Terms of a Negotiated Settlement?” Available at: http://www.mfa.gov.tr/where-do-the-parties-stand-in-terms-of-anegotiated-settlement .en.mfa.

VII Referring to the 2004 referendum for the reunification of Cyprus, Özdil Nami added that "the Turkish Cypriot people have clearly done their part and utilized their right to self-determination toward the establishment of a new partnership in the island

https://www.washingtontimes.com/news/2014/sep/30/turkish-republic-northern-cyprus-ministry-foreign$L$.

VIII Ministry of Foreign Affairs of the Republic of Cyprus, Address by the Minister of Foreign Affairs Markos Kyprianou at the dinner organized by the Cypriot Brotherhood, at the House of Commons in 2008. Available at:http://www.mfa.gov.cy/mfa/mfa2016.nsf/8effcb841e067c1cc2257f950023ec01/af1f23d1e4607c9dc2257f a0004581b8?OpenDocument.

IX In any case, a new federal structure, according to Greek Cypriots, will necessarily accommodate the transferring of authority to the existing Turkish Cypriot administrative apparatus and retain some of its 'accrued' obligations and liabilities under the federal (central) government.

x For more see: Vienna Convention on Succession of States in respect of Treaties (1978)

XI Eroglu stated in December 2012 that "a possible settlement of the Cyprus issue could be viable only if it is based on the existing realities on the island," which acknowledges that "there were two different people having two separate languages, religions, nationality and origin and two different states." Turkish Cypriot leader M. A. Talat stated before the parliamentary assembly of the Council of Europe on 1 October 2008 that he wants to establish a new partnership state in Cyprus, which will be composed of two constituent states of equal status.
}

Avaliable at:

http://www.mfa.gov.cy/mfa/mfa2016.nsf/8effcb841e067c1cc2257f950023ec01/af1f23d1e4607c9dc2257fa0 004581b8?OpenDocument.

XII Turkish Cypriot and Turkish Media Review.5 February 2016. "Presidential spokesman of TRNC government Baris Burcu denied the claim that Akinci supports a solution which will be achieved through the evolution of the Cyprus Republic “.

Avaliable at:

http://www.moi.gov.cy/moi/pio/pio.nsf/All/FF5FF9BDCECC26DEC2257F500049D6F6?OpenDocumen t\&highlight $=$ burcu $\% 20$ baris.

XIII Joint Declaration Statement by President Nicos Anastasiades and Turkish Cypriot leader Dervis Eroglu, 11 February 2014. For more see: UN Cyprus Talks. Available at: http://www.uncyprustalks.org/11-february- 
2014-joint-declaration-on-cyprus/.

XIV The type of electoral system set in place for electing federal government can be indicative of whether the two ethnic groups are treated as a single (unified) or conjoined (fragmented) national body.

XV SCR/541/1983 condemned the unilateral declaratory exercise of the self-determination right by the Turkish Cypriot community and the establishment of a politically sovereign Turkish Republic of Northern Cyprus in Northern Cyprus because of force outside an agreed framework.

\section{References}

- $\quad$ Alen André \& Peeters Patrick., 1998, 'Federal Belgium within the International Legal Order: Theory and Practice', in Wellens Karel (ed), International Law: Theory and Practice, Martinus Nijhoff Publishers, Hague, 122-124.

- Anderson Liam D., 2014, 'Ethnofederalism: The Worst Form of Institutional Arrangement...?', International Security, XXXIX, (1): 165-204.

- Anastasiades Nikos, 2016, 'President of the Republic of Cyprus Parliamentary Speech on the Resolution of the Cyprus Question', Politis Newspaper, 11 February 2016. Available at: http://www.politisnews.com/cgibin/hweb?-A=315626\&-V=articles.

- $\quad$ Berg Eiki, 2007, 'Examining power-sharing in persistent conflicts: De Facto Pseudo-statehood versus de Jure Quasi-federalism', Global Society, XXI (2): 199-217.

- Berg, Eiki, 2009, 'Re-Examining Sovereignty Claims in Changing Territorialities: Reflections from 'Kosovo Syndrome”, Geopolitics. XIV (2): 219-234.

- Booth Ken \& Wheeler Nicholas., 2008, The security dilemma: fear, cooperation and trust in world politics, Palgrave, Basingstoke.

- $\quad$ Brownlie Ian., 2010, Principles of Public International Law, Clarendon Press, Oxford.

- Buchanan Allen, 1997. 'Self-Determination, Secession, and the Rule of Law', in McKim Robert and McMahan Jeff (eds), The Morality of Nationalism, Oxford University Press, Oxford, 301-314.

- $\quad$ Burgess Michael, 2007, 'What needs to be done? Bicommunalism, Federation and Confederation in Cyprus', in Burgess Michael \& Pinder John (eds), Multinational Federations, Routledge, London, 127-149.

- $\quad$ Butt Ahsan I., 2011, 'Goodbye or See You Later: Why States Fight Some Secessionists but Not Others', APSA 2011 Annual Meeting paper: 1-47.

- Constantinides Aristoteles \& Christakis Theodore, 2017, 'Territorial Disputes in the Context of Secessionist Conflicts', in Kohen Marcelo \& Hebie Mamadou (eds), Research Handbook on Territorial Disputes in International Law, Edward Elgar Publishing, Cheltenham, 1-48. Available at: https://papers.ssrn.com/sol3/papers.cfm?abstract id=2927644.

- Cornell Svante E., 2002, 'Autonomy as a Source of Conflict: Caucasian Conflicts in Theoretical Perspective', World Politics, LIV (2): 245-276.

- $\quad$ Crawford James, 2006, The Creation of States in International Law, Clarendon Press, Oxford.

- Del Mar Katherine, 2013, 'The myth of Remedial Secession', in French Duncan, Statehood and SelfDetermination Reconciling Tradition and Modernity in International Law, Cambridge University Press, Cambridge, 79108.

- $\quad$ Ergün, Olgun M. \& Dirk Rochtus, 2008, 'Cyprus: The Belgian 'Tool Box' Revisited', Insight Turkey, X (4): 111-134.

- Erhürman Tufan, 2010. 'New Set of Negotiations in the Cyprus Problem: Federation for a Stable Democracy', Ankarabarreview, III(1): 35-41.

- Fitzmaurice Gerald, 1958, 'Third Report on the Law of Treaties, Yearbook International Law Commission', II, United Nations.

- Gudelevičiūte Vita, 2005, 'Does the Principle of self Determination Prevail over the Principle of Territorial Integrity?', International Journal of Baltic Law, II(2): 48-74.

- Hernadez Gleider I., 2013, 'Federated Entities in International Law: Disaggregating the Federal State?', in French Duncan (ed), Statehood and Self-Determination: Reconciling Tradition and Modernity in International Law, Oxford University Press, Oxford, 491-512.

- Héraud Guy, 1963, L’Europe des ethnies, Presses d'Europe, Nice. 
- International Crisis Group, 2014, 'Divide Cyprus: Coming to terms on an imperfect reality', ICG Europe Report No. 229: 1-43.

- 'ICJ Hears further Kosovo arguments': Balkan Insight, 2 December 2009. Available at: http://www.balkaninsight.com/en/article/icj-hears-further-kosovo-arguments.

- $\quad$ Kelsen Hans, 2003, Principles of International Law, Law Book Exchange, New Jersey.

- Ker-Lindsay James, 2011, The Cyprus problem: What everyone needs to know, Oxford University Press, Oxford.

- $\quad$ Koktsidis Pavlos I., 2017, 'Negotiating Under the Security Dilemma: A Loss-Framed Approach to the Question of Cyprus', Journal of Peace and Conflict Studies, XXIV (1): 1-31.

- Kovziridze Tamara, 2008, Hierarchy and Interdependence in Multi-level Structures: Foreign and European Relations of Belgian, German and Austrian Federated Entities, Vubress, Brussels.

- Krasner Stephen, 1999, Sovereignty: Organized Hypocrisy, Princeton University Press, Princeton NJ.

- Kurtulus Ersun, 2005. State Sovereignty: Concept, Phenomenon and Ramifications, Palgrave Macmillan, Basingstoke.

- $\quad$ Leigh Monroe, 1990, 'The Legal Status in International Law of Turkish Cypriot and the Greek Cypriot Communities in Cyprus', in Ertekün Necati Münir (1997) (eds), The Status of the Two Peoples in Cyprus: Legal Opinions, $2^{\text {nd }}$ ed., Okman Ltd., Lefkosa, 54-68. Available at: http://www.mfa.gov.tr/chapter5.en.mfa.

- Mavrogiannis Andreas, 2016, 'Greek Cypriot Chief Negotiator Presentation at the Democratic Party Conference on the Cyprus Question in Nicosia', (Author's notes).

- McEvoy Joanne \& O'Leary Brendan (eds), 2003, Power Sharing in Deeply Divided Places, University of Pennsylvania Press, Philadelphia.

- $\quad$ Moore Adam, 2016, 'Ethno-territoriality and ethnic conflict', Geographical Review, CVI (1): 92-108.

- Morelli Vincent, 2017, 'Cyprus: Reunification Proving Elusive', Congressional Research Service, 75700, USA. Available at: https://fas.org/sgp/crs/row/R41136.pdf.

- Murphy Alexander, 1996, 'The Sovereign State System as Political Territorial Ideal', in Biersteker Thomas and Weber Cynthia (eds), State Sovereignty as Social Construct, Cambridge University Press, Cambridge UK, 81-120.

- Pavković Alexander \& Radan Peter, 2007, Creating New states: Theory and Practice of Secession, Ashgate Publishing, Ltd., Farnham.

- Posen Barry, 1993, 'The security dilemma in ethnic conflict', Survival, XXV(1): 27-47.

- Putnam Linda \& Wondolleck Julia M., 2003, 'Intractability: Definition, Dimensions, and Distinctions', in Lewicki Roy, Gray Barbara and Elliott Michael (eds), 'Making Sense of Intractable Environmental Conflicts: Concepts and Cases', Island Press, Washington DC, 39-59.

- $\quad$ Richmond Oliver, 1999, 'Ethno- nationalism, sovereignty and negotiating positions in the Cyprus conflict: obstacles to a settlement', Middle Eastern Studies, XXXV(3): 45-63.

- $\quad$ Roe Paul, 1999, 'The intrastate security dilemma: Ethnic conflict as a 'tragedy?', Journal of Peace Research, XXXVI(2): 183-202.

- $\quad$ Roeder Philip, 2009, 'Ethnofederalism and the Mismanagement of Conflicting Nationalisms', Regional and Federal Studies, XIX(2): 203-219.

- $\quad$ Rose William, 2000, 'The security dilemma and ethnic conflict: Some new hypotheses', Security Studies, IX: $1-51$.

- Rusinow Dennison I. 1981, The Cyprus Deadlock: Forever or another Day?, American Universities Field Staff, Hanover, NH.

- $\quad$ Sack Robert, 1986, Human Territoriality: Its Theory and History, Cambridge University Press, Cambridge.

- Saideman Stephen M. \& Zahar Marie-Joelle (eds), 2008, Intra-State conflict, governments and security: Dilemmas of deterrence and assurance, Routledge, London.

- Schlicher Ronald, 2008, 'How virgin must the birth of a new post-solution state of Cyprus be?', Confidential Report by US Amb. to Cyprus, WikiLeaks ID Classification: 08NICOSIA287. Available at: https://wikileaks.org/plusd/cables/08NICOSIA287 a.html.

- $\quad$ Shaw Malcolm, 2003, International Law, Cambridge University Press, Cambridge.

- $\quad$ Snyder Jack \& Jervis Robert, 1999, 'Civil war and the security dilemma', in Walter Barbara \& Snyder Jack (eds), Civil wars, insecurity, and intervention, Columbia University Press, New York, 15-37. 
- $\quad$ Steinberger Helmut, 1967, 'Constitutional subdivisions of states or unions and their capacity to conclude treaties, Comments on Art. 5.2 Para. 2 of the ILC's 1966 Draft Articles on the law of the treaties', Zeitschrift für Ausländisches Offentliches Recht und Völkerrecht, XXVII: 411-428.

- $\quad$ Storey David, 2001, Territory: The Claiming of Space, Pearson and Prentice Hall, Harlow.

- Soysal Mümtaz, 1999, 'A solution for Cyprus through Statehood', Journal of International Affairs, IV(3): $1-7$.

- Sözen, Ahmet, and Kudret Özersay. 2006, 'The Annan Plan: State Succession or Continuity', Middle Eastern Studies, XLIII(1): 125-141.

- $\quad$ Tocci Natalie \& Kovziridze Tamara, 2004, 'Europeanization and Conflict Resolution: Case Studies from the European Peripher', JEMIE - Journal on Ethnopolitics and Minority Issues in Europe, I: 1-35.

- Toft Monica, 2001, 'Indivisible Territory and Ethnic War', Paper No. 1. Weatherhead Center for International Affairs, Harvard University: 1-46.

- Visone Tommaso, 2018, 'Eurosceptic Federalism: Paradoxes and Relevance of a long-running Critique of European Integration', Perspectives on Federalism, X(1): 26-40.

- Wolff Stefan, 2010, 'Approaches to Conflict Resolution in Divided Societies: The Many Uses of Territorial Self-Governance', Ethnopolitics Papers, V: 1-38.

- Wouters Jan \& De Smet Leen, 2001, 'The Legal Position of Federal States and their Federated Entities in International Relations - The Case of Belgium', Institute for International Law K.U. Leuven Working Paper No 7: 1-32. 